\title{
FAMILY AMYLOID POLYNEUROPATHY - BEYOND THE ORGANIC MANIFESTATIONS
}

\author{
Cruz e Sousa, D.; Ramos, S.; Jesus, B; Correia, J. *Mendes, J. ** \\ ${ }^{*}$ Residents of Psychiatry in DPSM of Guarda U.L.S ${ }^{* *}$ Psychiatrist in DPSM of Guarda U.L.S
}

\section{Objectives}

Describe neuropsychological manifestations in a case of Family Amyloid Polyneuropathy (FAP).

\section{Background and aims}

Family Amyloid Polyneuropathy (FAP) was first described in Portugal (1939). It is a progressive hereditary and multisystemic disease. Neurologic and psychiatric manifestation of FAP include psychosis and progressive dementia.

\section{Materials and methods}

Presentation of a clinical vignette and nonsystematic review.

\section{Case Report}

We present the case of a 57-years-old patient assessed in the emergency department for "behavioral changes with hallucinatory activity in the context of probable demential syndrome". She had two previous psychiatric admissions with diagnosis of psychosis SOE /or dementia in evolution. Medical history was obtained: she suffered from PAF with central nervous system deposit (CNS) of amyloid, focal cryptogenic epilepsy, blindness and had had a liver transplant. Serum analysis and imaging evaluation were normal. She was admitted to the department of psychogeriatrics for psychopathological stabilization and diagnostic clarification. The hospital stay was uneventful. She scored 11/30 in the Mini Mental State Examination. No evidence of disturbances in thoughts, perception or mood changes was observed. She was discharged with a diagnosis of dementia, probably due to amyloid deposit in the CNS.

\section{- Conclusions}

FAP is the most disabling hereditary polyneuropathy of adult onset, though psychiatric symptoms may also manifest. Therefore, adequate medical care must include assessment of signs and symptoms of psychiatric illness, in order to preserve psychosocial functioning and allow for better quality of life of patients and their families.

PAF is a multiorgan disease with predominantly neurological manifestations. In turn, leptomeningeal amyloidosis is associated with the development of progressive dementia.

Despite the short average life expectancy of these patients, it is essential to be alert to the signs and symptoms of psychiatric illness that limit their social interaction and cause a great negative impact not only on the individual but also on their family and social structure.

Bibliography:

Martins, T; Prereira; PhD, L. Polineuropatia Amiloidótica Familiar -Uma Abordagem Neuropsicológica. Panamerican Journal of Neuropshychology Volumen 8. Número 2. Noviembre 2014. DOI 10.7714/cnps/8.2.602;Eiras, C. Qualidade de Vida em doentes com Polineuropatia Amiloidótica Familiar Tipo 1 após três anos do Transplante Hepático e sua relação com a Psicopatologia. Braga 2011; Silva, A. Proteómica diferencial da polineuropatia amiloidótica familiar: para além da genética. Lisboa 2011. 